\title{
The effect of Blogs as a means of formative assessment on enhancing writing skills and attitudes towards them
}

\author{
By \\ Heba M. Mohamed, PhD \\ Associate professor of TEFL \\ Faculty of Education, Beni Suef University \\ Hebamoustafa990@gmail.com
}

\begin{abstract}
This study examines how the achievement of students was affected by using blogs as considered a means of formative assessment, and it also checked the participants' attitudes towards them. Participants $(\mathrm{N}=60)$ were divided into two equal groups: experimental and control groups. Instruments include an achievement test based on writing skills and a learner attitudes' scale. Results showed that there were statistically significant differences between the mean score of the experimental and control groups in favor of the experimental group. The study concluded that using blogs as a means of formative assessment proved to be effective in improving freshmen students at the faculty of education writing skills and attitudes towards blogs.
\end{abstract}

Key words: Formative assessment- blogs - reflection- writing

\section{Introduction}

Using technology in teaching has become an urgent prerequisite in any educational system nowadays, especially at university level as technological devices either computers, lap tops, ipads, iPods, tablets or even smart phones have become one of the salient features of the life of all people in general and adults in particular. There are many technological applications that have been proven to be effective in the educational area such as web quests, wikkis, and weblogs.

This study adopted the ideas of social constructivism which were called out by both of Piaget (1955) and Vygotsky (1978) who supported an active learning trend where students learn well by doing and collaborating in their social groups. Social media reflects the constructivist approach to e-learning by providing students with personal sets and engaging them in social networks. (Awodele, et al. 2009; Gunawardena, et al., 2009; Angele , 2008). The social constructivist approach indicates that humans acquire knowledge through interacting and sharing ideas with each other.

Blogging can be considered one of the best ways to teach and practice writing skills.( Glymph, 2012).In spite of the positive expectations of the use of blogs as a new technology in language education (Campell, 2004; Pinkman, 2005; Fitze, 2006), it seems to take 
several more years before it to be a stable teaching tool ( Miyazoe and Anderson,2010). This paper considers the effects of using blogs on developing formative assessment as well as the attitudes towards blogging. The study investigates the use of blogs as it matches the reality for learners those days in which blogs are considered popular methods of day-to day communication (Oblinger and Oblnger, 2005; Miyazoe and Anderson, 2010).

\section{Review of literature}

\section{Rationale of using blogs in learning environments}

The main theory upon which blogs are based is " collaborative constructivism" as ( Garrison and Akyol, 2009) clarified that using web 2 resources such as blogs in teaching is useful as it's focused on a certain problem that requires students to be involved in a purposeful discourse to construct meaning and share meaning in a collaborative way as well as validating understanding. Educationists all over the world recommended the use of web-based modes of instruction to improve learning in higher education. Garrison and Vaughan (2008) ensure that higher education institution should encourage the use of online learning, so educators should use web- based approaches that focus on giving students a chance to engage their professors and peers in critical and creative reflection which are considered the conventional ideals of higher education. A great number of researchers insisted that web-based communication tools like web blogs can improve teaching and learning in schools across grade levels (Stewart, 2011).

\section{Blogs and reflection}

It is indicated that effective learning ten years ago was a result of inquiry, reflection and continuous professional growth ( Harris and Johnson,01998). Reflection can be defined as a process of internal dialogue facilitated by thinking or writing and through an external dialogue and reflection together with others ( Clarke, 2003). Also, Saylor suggests that reflection is a hard thing as it requires one to analyze to make judgment ( Saylor as cited in Palmer, Burns \& Bulman , 1994).

Different methods may be recently used to make reflective dialogue easy to support group learning. The development of collaborative communities of learners, including communities facilitated by technological tools has appeared crystally in literature ( Lieberman, 1995). The use of online blogs has increased as tools to share opinions and views. They are frequently used as private diaries ( Herring et al, 2004).Also they can support written dialogue by combining internal and external reflection. 


\section{Heba M. Mohamed, PhD}

Some studies tackled blogging as a reflective tool that is used to promote higher order thinking (Brockbank \& McGill, 1998; Perschbach, 2006) as it can facilitate the process of publishing the students' work as self-reflection. Indeed, several studies recommended the trend of the learner-centered constructivist environment (Ben-Ari, 2001; Gokhale, 1997) which is common now in some institutions which are interested in using technology as an asset in the teaching process. The educational uses of blogging have been used in different researches (Wrede , 2003; Downes , 2004; Williams \& Jaobs , 2004;Fiedler , 2003b). The Current research indicates the uniqueness of the use of blogging as a means of formative assessment in developing writing skills.

According to the technology acceptance model, the more the technology is easy to use, and useful, the stronger will be attitudes towards technology, and the greater will be the intention to use it (Stoel \& Lee , 2003 , p.365). A blog is considered as easy to use as anyone can publish on it ( Lin \& Yuan, 2006); Divitini et al. , 2005). There are many studies that clarify the merits of using blogs in class (Divitini et al, 2005; Glogoff , 2007; Magg, 2005; Williams \& Jacobs , 2004).

Reflection leads to good learning as illustrated and indicated by many authors (Moon, 1999; Stickel \& Trimmer, 1994; Bouner, 2003; Wood \& Lynch , 1998). Moon (1999) designed a model called " a map of learning) in which he mentioned that reflection is the means through which learning is integrated into the cognitive structure and relating it to the prior knowledge of the learner. Whang (2002) denoted that a "journal buddy" can help pre-service teachers in their reflection and meaning construction processes.

\section{Blogs and Learning}

As a type of personal publishing (Downes, 2004), the blog is a text-based online tool which enables the author to publish in a chronological order. This feature distinguishes it from other web-based publishing resources such as web- pages ( Viegas , 2006). One of the other features that enable blogs as a feedback from the audience through comments (Burgess, 2006).

Blogs can help teachers make students understand lessons (Purgess, Payne, et al ,2009) as they contextualize learning: firstly through students' comments, teachers can know the problems. Secondly, blogs can be permanent resources of information. Also students can ask about any vague information, so it is considered a means for an ongoing feedback and reshaping of learning activities. 


\section{Blogs and Formative assessment}

Blogs can be used as a tool for formative assessment. Formative assessment is not a new concept, and any teacher who adjusts his or her teaching during instruction on the basis of evidence of student understanding and performance is employing formative assessment (Popham, 2008; Shepard, 2005).Traditional formative assessment techniques such as student questioning or quizzes are limited in how many students are assessed or can be difficult to analyze during class. It is collecting and analyzing large sets of data from multiple students, groups and class sections with speed and accuracy, regardless of the physical location of students. Blogging employs online technologies to create environments that mirror collaborative professional research communities in which colleagues evaluate each other's work and ideas on a continual basis. Similarly, teachers create blended and online classroom activities in which students analyze whole class data using blogs. These activities help students gain an understanding that the learning enterprise requires collaboration, independent verification, and peer review.

Assessments can help teachers determine student progress and adjust lessons according to individual needs. They can help students understand how they learn and how they can enhance their own learning. Blogs can present a great deal of excitement as well, encouragement and a more meaningful experience. ( De Feritas \& Oliver, 2005; Gunn, 2010). Other benefits of blogs may be the availability of correcting work before submitting it (Lobnes, 2003; Curtis, et al, 2009),

\section{The present study}

\section{Method}

\section{Participants}

The participants of the study were voluntarily participated. They were sixty English major students at the faculty of education, , Beni Suef University, Egypt. They were divided into two equal groups: experimental and control.

\section{Research Instruments and Materials Instruments}

Data were collected by the researcher in the 2015-2016 academic year using two instruments: A pre-post writing test which aimed at assessing English writing skills of first year students at the faculty of education, English section. It consists of five questions. It includes both essay and objective questions. An attitudes' scale which aimed at checking if using blogs in learning can help in changing the participants' attitudes towards them. It consists of three main dimensions which are: Blogging \& Academic progress, interaction with blogs, and merits of blogs. 


\section{Heba M. Mohamed, PhD}

\section{Materials}

The researcher used two materials in the present study:

1) A checklist of writing skill. It consisted of five parts as follows:

a) Mechanics of writing which includes (Correct spelling - Using appropriate punctuation).

b) Organization which includes (Appropriate writing of introductionCoherence-Cohesion -Appropriate writing of conclusion).

c) Content that includes (Writing meaningful sentences-Writing wellstructured sentences -Writing meaningful translation -Providing good responses to situations).

d) Grammar which includes (Subject verb agreement -appropriate usage of grammatical rules.

e) Vocabulary (Using a suitable range of vocabulary- Good choice of vocabulary).

2) Blogs designed by the researcher in an attempt to enhance the participants' writing skills which are entitled:

- What's a paragraph?

- Characteristics of a good paragraph .

- Mechanics

- Organization of a good paragraph.

- Content of a good paragraph.'

- Grammar

- Vocabulary

In addition the researcher guided and helped the experimental group to design their own blogs using the free website www. blogger .com in order to express themselves through them as well as contacting with their peers and her.

\section{Hypotheses}

The present study attempted to examine the following hypotheses:

1. There is a statistical significant difference between the mean scores of the experimental group students and the mean scores of the control group students regarding the post administering of the attitudes' scale in favor of the experimental group.

2. There is a statistical significant difference between the mean scores of the experimental group students and the mean scores of the 
control group students regarding the post administering of the achievement test in favor of the experimental group.

\section{Procedures}

1. Two groups (60 students); 30 of them in the experimental group, and the other thirty in the control group in the faculty of education, first year, English department, basic section were used.

2. Subjects (experimental and control groups) administered the attitudes' scale in one class session. This was at the beginning of the first academic year 2015-2016.

3. Subjects (experimental and control groups) administered the achievement test as a pre-test in one class session. This was at the beginning of the first academic year 2015-2016.

4. The experimental treatment was conducted using blogging in teaching "Essay writing". The control group was taught by the traditional method.

5. The achievement test was post-administered to both the experimental and control groups. This step was conducted to reveal the change in achievement of students, if any, for both the control and the experimental groups. Thus, the post-test aimed at measuring the effect of using blogging, if any, to enhance achievement of the experimental group after conducting the current study.

6. The attitudes' scale was post- administered to the study groups to reveal the change, if any, in their attitudes towards blogging.

Students were required to complete weekly written tasks (based on the module topic) and publish to their own personal blog space encouraging assessment effort distribution across weeks. They created an online identity as educational professionals, and used the taught sessions to develop their writing in groups which provided timely tutor and peer feedback on their work throughout the assessment. This work then directly contributed to the summative submission for the module.

\section{Data analysis}

After collecting the data from the test \& attitude's scale, SPSS 19 was used to analyze the collected data." $t$ " test for independent variables was used during the analysis process. 


\section{Heba M. Mohamed, PhD}

\section{Results}

As for the first study instrument which is the pre-posttest, the researcher calculated its validity by finding the correlation coefficient between the marks of each question and the total scores of the test. It was $0.80,0.87,0.88,0.86,0.85,0.88,0.86$, and 0.87 for the eight questions. Also the reliability of the test was calculated by using alpha technique. It was $0.59,0.63,0.67,0.61,0.57,0.59,0.63$, and 0.66 . (Table 1 )

Table (1) validity and reliability of the pre-post achievement test

Questions

Validity

Reliability

$\begin{array}{lll}\text { 1. mechanics } & 0.87 & 0.63 \\ \text { 2. grammar } & 0.88 & 0.67 \\ \text { 3. vocabulary } & 0.85 & 0.57 \\ \text { 4.organization } & 0.88 & 0.59 \\ \text { 5. content } & 0.86 & 0.63\end{array}$

In order to check the equivalence of both of the experimental and control groups before experimentation, the pre-test was administered to both of them. It has been proven that both of the two groups have about the same level as it is clear in table (2)

Table (2) means, $s . d$, " $t$ " of experimental and control groups in pre administration of the achievement test

$\begin{array}{ccccc}\text { Questions } & \text { Group } & \text { Means } & \text { S.D } & \mathrm{t} \\ \text { 1. grammar } & \text { Exp. } & 12.88 & 1.92 & 0.47 \\ & \text { Cont. } & 12.66 & 1.67 & \\ \text { 2. mechanics } & \text { Exp. } & 5.89 & 1.64 & 0.68 \\ & \text { Cont. } & 6.19 & 1.73 & \\ \text { 3 vocabulary } & \text { Exp. } & 3.73 & 1.42 & 0.69 \\ & \text { Cont. } & 3.84 & 1.33 & \\ \text { 4.organization } & \text { Exp. } & 9.46 & 2.49 & 0.53 \\ & \text { Cont. } & 9.84 & 2.91 & \\ \text { 5. content } & \text { Exp. } & 4.22 & 1.74 & 1.01 \\ & \text { Cont. } & 4.67 & 1.64 & \end{array}$

After experimentation, the researcher administered the test again to check if there is a change in the performance of students or not. It has been shown that there is a difference in the performance of students in the different skills of writing. The mean scores of the experimental group in the grammar questions were "19.96" while the control group means scores were "15.45". This change may be a result of the use of blogs in teaching which were used in the current study. Concerning the mechanics' questions, the mean scores of the experimental group were "9.74" for the experimental group, and "7.76" for the control group. As there were many activities that required many forms of writing, there were more practice, 
more reflection, and more peer-criticism and also the instructor's opinion, the level of students changed a lot, and achieved high progress and achievement. As for "vocabulary" questions, the mean scores of the experimental group were "6" while "4.37" for the control group. Concerning the question of organization, the mean scores of the students of the experimental group were "17.97" while "11.21" of the control group. As for the questions of content, the mean scores of the experimental group was "9" while "6.28" for the control group (Table 3). Table (3) means, $s$. d, " $t$ " of experimental and control groups in post administration of the achievement test.

$\begin{array}{lccccc}\text { Questions } & \text { Group } & \text { Means } & \text { S.D } & \text { t } & \begin{array}{c}\text { Effect } \\ \text { size }\end{array} \\ \text { 1. grammar } & \text { Exp. } & 19.96 & 1.99 & 9.21 & 0.59 \\ & \text { Cont. } & 15.45 & 1.73 & & \\ \text { 2. mechanics } & \text { Exp. } & 9.74 & 0.83 & 8.16 & 0.53 \\ & \text { Cont. } & 7.76 & 1.01 & & \\ \text { 3 vocabulary } & \text { Exp. } & 6 & 0.62 & 6.81 & 0.44 \\ & \text { Cont. } & 4.37 & 1.13 & & \\ \text { 4.organization } & \text { Exp. } & 14.97 & 1.27 & 7.53 & 0.49 \\ & \text { Cont. } & 11.21 & 2.37 & & \\ \text { 5. content } & \text { Exp. } & 9 & 1.61 & 7.12 & 0.74 \\ & \text { Cont. } & 6.28 & 1.28 & & \end{array}$

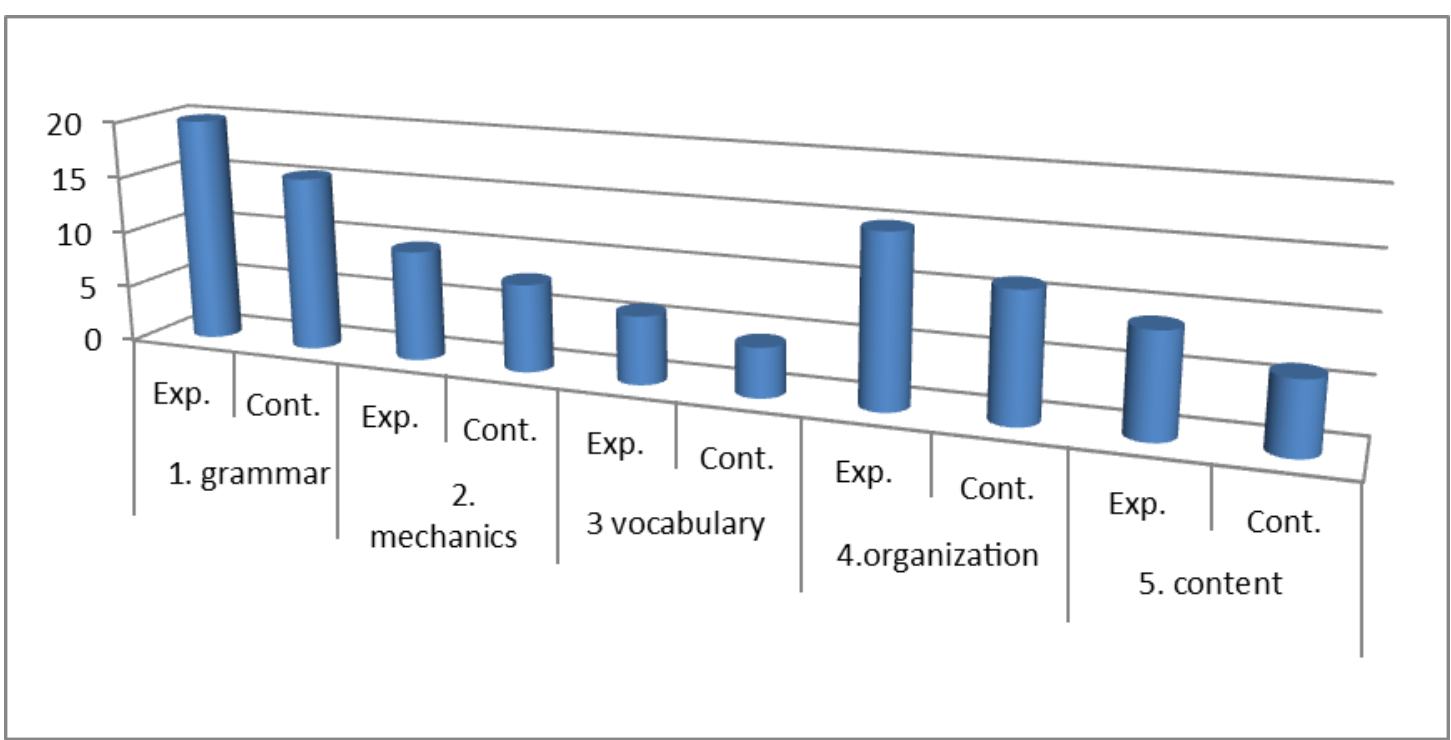

Figure (1) Comparison between experimental \& control groups in post administration of achievement test

In order to check if there is a change in the opinions of students towards blogging, the researcher developed a scale that is divided into three main dimensions: Blogging \& Academic progress, interaction with 


\section{Heba M. Mohamed, PhD}

blogs, and merits of blogging. In order to check the validity of the scale, the correlation coefficient between the marks of each dimension and the total scores of the attitudes' scale ranges from 0.66 to 0.71 .( Table 1 ). The researcher used Alpha cronbach technique to measure the reliability of the test. It ranged from 0.66 to 0.71 . Those values are high and significant at 0.01 .

Table (4) validity \& Reliability of the attitudes' scale

$\begin{array}{lcc}\text { Attitudes' dimensions } & \text { reliability } & \text { validity } \\ \begin{array}{l}\text { 1. Blogging \& } \\ \text { Academic progress }\end{array} & 0.81 & 0.66 \\ \begin{array}{l}\text { 2. Interaction with } \\ \text { blogs }\end{array} & 0.80 & 0.67 \\ \text { 3. merits of blogging } & 0.82 & 0.71\end{array}$

To ensure the equivalence of both of the experimental and control groups in their reactions to the items of the scale, it was administered for both of them.

Table (5) Means, S.D, " $t$ " test scores of experimental \& control groups in pre administration of the attitudes' scale

\begin{tabular}{lllll} 
Dimensions & Group & Means & S.D & t \\
1. Blogging \& & Exp. & 13.66 & 3.52 & 0.89 \\
Academic & Cont. & 12.87 & 2.54 & \\
progress & Exp. & 15.96 & 2.78 & 0.33 \\
$\begin{array}{l}\text { 2. Interaction } \\
\text { with blogs }\end{array}$ & Cont. & 15.71 & 1.63 & \\
\multicolumn{1}{c}{ 3. merits } & Exp. & 14.5 & 1.63 & 0.27 \\
of blogging & Cont. & 14.39 & 1.69 &
\end{tabular}

After administering the suggested lessons to students of the experimental group while the control group was taught using the traditional method of teaching, the researcher took their reactions again towards blogs.

Table (6). Means, S.D, " $t$ " test scores and effect size of the experimental \& control groups in post administration of the attitudes' scale

\begin{tabular}{|c|c|c|c|c|c|}
\hline Dimensions & Group & Means & S.D & & Effect size \\
\hline Blogging \& & Exp. & 18.46 & 1.32 & 6.51 & 0.42 \\
\hline $\begin{array}{l}\text { Academic } \\
\text { progress }\end{array}$ & Cont. & 14.87 & 2.66 & & \\
\hline Interaction & Exp. & 19.78 & 1.47 & 8.48 & 0.55 \\
\hline with blogs & Cont. & 16.01 & 1.89 & & \\
\hline merits & Exp. & 19.87 & 1.43 & 7.91 & 0.52 \\
\hline blogging & Cont. & 15.64 & 2.5 & & \\
\hline
\end{tabular}


As it is clear in table (6) the reactions of the experimental group changed a lot before and after the experimentation. As they knew about blogs and used them in their study, they began knowing more about the use of blogs in increasing their academic progress, as well as knowing more about how to interact with blogs and comment on their friends' blogs in order to reflect on their work. On the other hand, they can be benefited from the opinions of others as well as the opinions of the instructor. Also all "t scores are high and significant at 0.01 level. The effect size also was high and significant. It's also noticed that the scores of the control group changed a little from the pre- administration as they heard about the benefits of blogs from their peers at the college.

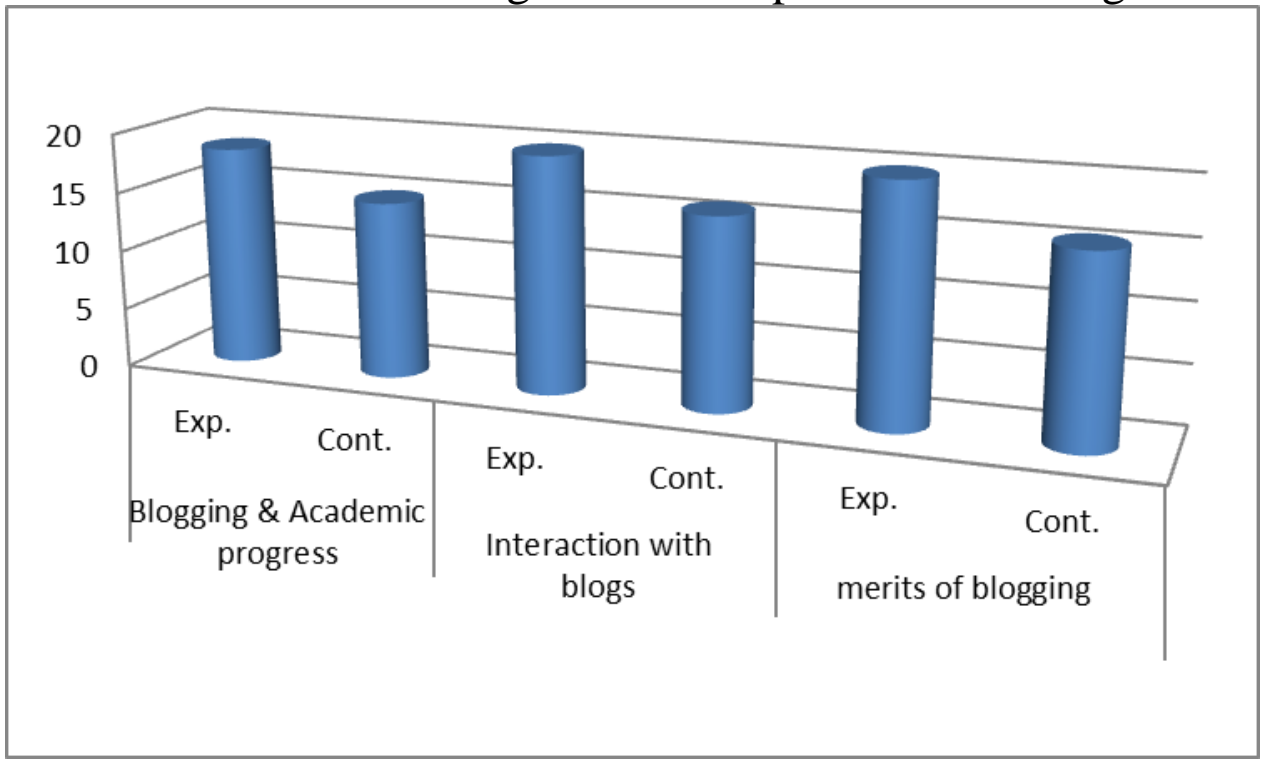

Figure (2) comparison between experimental \& control groups in post administration of the attitudes' scale

\section{Discussion and conclusion}

As a result of the great development in technology which was a result of the need for student-centered education rather than teacher-centered one, different approaches were used for reflection and formative assessment such as electronic portfolios, blogs, wikis,). Many studies talked the role of electronic portfolios in formative assessment as they cover all the positive features of the traditional ( paper and pencil) portfolios but also reflect a student growth in all aspects, thus they reflect a real image of the learners ( Change, 2001; Weller, 2004; Gulbahar \& Koss, 2006). Other studies focused on the use of blogs as a formative means of assessment (Churchill, 2009; Divitini et al, 2005).Most participants in the current study reacted positively to the attitudes' scale as they agreed on the importance of blogs as a tool of learning as well as the easy way to exchange knowledge. They felt 
the community atmosphere that helped them learn in a warm atmosphere.

Churchill (2002); Ducate and Lomicka (2008); Ellison and Wu (2008); Goldman et al (2008) and Halic et al (2010) ensured that most students had a positive experience with the blog-based learning. Most of the participants ensured that blogs offered them chances to reflect on course- related concepts outside of the class. Sharma and Xie (2008) also agreed that the use of blogs lead to the development of social relations among participants. This was also focused on by Garrison et al. 2000); Garrison \& Cleveland- Innes, 2005 who indicated that those relationships may help in deep learning. The findings of the current research agreed with EEllison and Wu ,2008; Ducate and Lomicka, 2008; Churchill, 2009; Kerawalla , Minoocha , Kirkup, \& Canole , 2009 who supported students' support for peer feedback on their blog posts.

Blogs have been proven to increase students' interactivity (Kim, 2008; Lin et al., 2006). Blogs with their chronological features suit classroom activities, tasks and homework ( Qi and Canadan , 2006). The students using blogs can keep all their work easily as well as they can check them anytime anywhere that is considered one of the great benefits of blogs.

Empirical evidence suggests that university students have a positive attitude towards the integration of blogs into learning as most of the reviewed studies showed that students preferred reading the blogs of their peers to their own blogs for learning purposes. Halic,O , Lee , D , et al . 2010; Churchill, 2009; Ducate \& Lomicka, 2008; Ellison \&Wu, 2008; Shim \& Guo, 2009; Xie, Ke, \& Sharma, 2008).

Some studies indicated that students were happy while commenting on their peers' blogs ( Lonhnes,2003) ,but others found out that some students did not prefer that (Armstrong et al 2004; Curtis et al 2009; Shih-Hsien ,2009).In the current study, the researcher always urges students to comment on others' work to increase interactivity.

Painter (2009), Blair and Godsall (2006) mentioned that authentic , technology-based assessment help students whatever their abilities to show their progress through the year no matter their beginning level of competence, because assessment will give time for personal reflection and cognitive growth .Through the current study, the researcher noticed the difference in students' writings in the beginning blogs and the last ones.This was indicated also in some studies like (Sun, 2010; Pob, 2009). 
Georgescu (2010) mentioned that some problems may be an obstacle before students in using blogs is their access to computers and internet, their level of computer literacy, plagiarism, and the time needed to instruct them on using a blog and to educate them on blog's content issues. In the current study the researcher didn't find any problems concerning this as students' were equipped with their smart phones that enable them to be access to internet easily as well as the easily - used interface of blogs that enabled them to use them without finding any problems.

\section{Limitations and directions for future research}

Research is still needed on the suitable learning strategies that may be used side by side with blogs to achieve more progress in classrooms. Also the infrastructure in Egypt in some schools, especially in rural places are still limited that can be a problem that may face using technology in the classrooms.

\section{Conclusion}

It has been concluded that blogs encouraged deeper engagement with readings and literature, wider knowledge and breadth/depth of study clarified understanding through a combination of formal comments, informal examples and face-to-face discussion .Blogs can be stimulating and exciting assessment formats. The students shared their experiences of teaching blogging, outlining challenges and highlights. The discussion drew on the feature of the technological tools of web 2 representing in blogs to scaffold the pedagogical view that personal and peer-to-peer feedback on draft writing develops academic independence, confidence and identity.Practical insights in how to structure activities enabled participants to make links with their own practice and disciplinary contexts.The sessions were interactive with questions, tasks and inductive strategies to engage participation threaded throughout. For example, participants discussed some issues related to the required activities of the modules. Through their active participation, they reflect on the influence of the blogging medium on effort, engagement and students' learning.

According to the results of the current study, the following recommendations can be set:

- Posing more open-ended questions for students to blog about.

- Encouraging students to comment more on their peers' blogs.

- Asking students to be more open minded while reading comments.

- Training students on how to deal with technical devices properly. 


\section{Heba M. Mohamed, PhD}

\section{References}

Armstrong, L.,M.Berry and R.Lamshed (2004). Blogs as Electronic learning journals, e-journal of Instructional Science and Technology, available at: www. usq.edu.au/electpuble-jlists/docs/No17no1/currentractice/blogs.htm.Retrieved at $8^{\text {th }}$ April 2015.

Awodele, O, Idowu,S.,Anjorin, O., Adeire, A., \& Akpore,V. (2009). University enhancement system using a social networking approach : Extending elearning. Issues in informing science \& information technology, 269283.

Angeli, C. (2008).Distributed cognition: A framework for understanding the role of computers in classroom teaching and learning. Journal of Research on Technology in Education, 34(3), 250-273.

Blair, R. \& Godsall, L.(2006). One schools' experience in implementing eportfolios: lessons learned. Distance learning, 3(3), 15-24.

Bouner, T. (2003). Assessing reflective learning. Education Training, 45(5), 267-272.

Burgess, J. (2006). Blogging to learn, learning to blog. In A. Bruns, \& J. Jacobs (Eds.), Uses of blogs (pp. 105-115). New York, NY: Peter Lang Publishing.

Campbell, A,2004.Using live Journal for authentic communication in EFL classes. The Internet TESL Journal. Retrieved from: http://iteslj.org/techniques/campbell-livejournal/. Retrieved at $10^{\text {th }}$ March 2015.

Chang, C. (2001); A Study on the Evaluation and Effectiveness Analysis of Web-Based Learning Portfolio WBLP.(British Journal of Educational Technology, 32 (4), 435-458.

Churchill, D. (2009). Educational applications of Web 2.0: Using blogs to support teaching and learning. British Journal of Educational Technology, 40(1), 179-183.

Clarke, M. (2003). Reflections : Journals and reflective questions a strategy for professional learning. NZARE/AARE Conference. New Zeland.

Curtis,S; Alexander, A; Sherrington, P.(2009). Placement blogging : The benefits and limitations of online journaling, Eliss: Enhancing learning in the social sciences (3)1, pp. 35-40.

De Fertas , S; Oliver, M (2005). Does e-learning policy drive change in higher education? A case study relation models of organizational charge to elearning impementatio. Journal of Highr Education policy and management. 27(1),81-96.

Divitini, M; Haugdokken, O, \& Morken , E.M (2005).Blog to support learning in the field : Lessons learned from a fiasco. In proceedings of the fifth IEEE International Conference of Advanced Learning Technologies (ICALT 05).

Downes, S. (2004). Educational blogging. Educause review, 39, 14-27.

Ducate, L. C., \& Lomicka, L. L. (2008). Adventures in the blogosphere: From blog readers to blog writers. Computer Assisted Language Learning, 21(1), 9-28. 
Ellison, N. B., \&Wu, Y. (2008). Blogging in the classroom: A preliminary exploration of student attitudes and impact on comprehension. Journal of Educational Multimedia and Hypermedia, 17(1), 99-122.

Garrison, D., \& Akyol, Z. (2009). Role of instructional technology in the transformation of higher education. Journal of Computing in Higher Education, 21(1), 19-30.

Georgescu, C.(2010).Using blogs in foreign language teaching. Petroleum-Gas university of Ploiesti Bulletin, Educational Sciences Series, G2(1A), 186-191.

Glogoff , S. (2007). Blogging in an online course: A report on student satisfaction among fist-time bloggers.

Glymph,O (2012). The effect of the private classroom blog on the acquisition of formal writing proficiency with Spanish III High school students. Liberty University.

Gulbahar, Y; Koss,S.(2006).Perceptions of Pre-service Teachers about the Use of Electronic Portfolios for Evaluation. Journal of Faculty of Education Sciences,.2006,9(3),pp.75,93, Ankara University.

Gunawardena, C., Hermns, M., Sanchez, D., Richmond , C. , Bohley, M., \& Tuttle , R. (2009).A theoretical framework for building online communities of practice with social networking tools. Educational Media International, 49(1), 3-16.

Gunn, C. (2010). Sustainability factors for e-learning initiatives. ALTJ,18(2),89-103.

Halic,O , Lee , D , et al . (2010) . To blog or not to blog: Student perceptions of blog effectiveness for learning in a college-level course, Internet and Higher Education, 13 ,PP 206-213.

Harris, M.K. \& Johnson, P.E. (1998). A large-scale schools, higher education collaboration to implement systematic change in mathematics teaching and learning. International journal of mathematical Education in Science and Technology, 29(5), 697-707.

Herring , S, Scheidt, L. Bonus , S. 7 Wright, E.(2004).Bridging the gap : A genre analysis of weblogs. System Science, 2004. Proceedings of the 37th Annul Hawaii International Conference.

Huck, S.W. (2007). Reform in statistical education. Psychology in the schools, 44, 527-533.

Huffaker , D. (2005). The educated blogger: Using weblogs to promote literacy in the classroom. AACE Journal, pp. 391-398.

Kim, H. (2008). The phenomenon of blogs and theoretical model of blog use in educational contexts. Computers \& Education, 51, pp. 1342-1352.

Lieberman, A (1995). Practices that support teacher development. Phi Delta Kappan, 76(8), pp.591-596.

Lin , H.T., \& Yuan , S.M. (2006). Taking blog as a platform of learning reflective journal . ICWL, pp. 38-47. 


\section{Heba M. Mohamed, PhD}

Lin, W.,Yuan , S. , Murakami, M., Kakusho, K \&Minoh, M. (2006). Blog as a tool to develop e-learning experiences in an international distance course. Proceedings of the sixth IEEE International Conference on Advanced Learning Technologies.

Lohnes,S. (2003). Weblogs in education : Bringing the world to the liberal arts classroom, The NITLE News (2)1, pp. 99-102.

McCorkle, B. (2010). English 109.02 : Intensive reading and writing II ,Reading, Blogging, Composition Studies, 38(1), 109-119. Retrieved from http:// web.ebscohost.com.ezproxy.liberty.edu.

Miyazoe,T\&Anderson,T(2010).Learning outcomes and students' perception of online writing: Simultaneous implementation of a forum,blog, and wiki in an EFL blended learning setting. System (38),pp.185-199.

Moon, J.A. (1999). Reflection in learning and professional development : Theory and practice . London Sterling, VA : Kogran Page: Stylus pub.

Oblingr,D and Oblinger,J,2005. Educating the Net Generation . Retrieved from http://www.educause.edu/educatingthenetgen.

Painter, D. (2009). Providing differentiated learning experiences through multigenre projects, Intervention in school and clinic , 44(5), 288-93.

Palmer, A,M,Burns , S., \& Bulman , C. (1994). Reflective practice in nursing. Oxford: Blackwell Science.

Paulus, T., Evans, K., Halic, O., Lester, J., Taylor, J., \& Spence, M. (2009). Knowledge and learning claims in blog conversations: A discourse analysis in social psychology )DASP) perspective. In C. O'Malley, D. Suthers, P. Reimann, \& A. Dimitracopoulou )Eds.), Computer-supported collaborative learning practices: CSCL 2009 Conference Proceedings, International Society of Learning Sciences. (pp. 93-97).

Pinkman,K,2005.Using blogs in the foreign language classroom: encouraging learner independence. The JALT CALL Journal 1(1),12-24.

Pop,A. (2009). Quality and the new technologies (NT) in higher education foreign language instruction. Annals of DAAAM\& Proceedings, 17211722.

Qi, Y., \& Candan, S. (2006). CUTS : Currature- based development pattern analysis and segmentation for blogs and other text streams. In proceedings of the $17^{\text {th }}$ conference on hypertext and hypermedia, pp. 110.

Shih-HsienmY. (2009).Using blogs to enhance critical reflection and community of practice. Journal of Educational Technology \& Society, $12(2), 11-21$.

Shim, J. P., \& Guo, C. (2009).Weblog technology for instruction, learning, and information delivery. Decision Sciences, Journal of Innovative Education, 7(1), 171-193.

Stickel, S.A. \& Trimmer, K., J. (1994). Knowing in action: A first year counselor's process of reflection. Elementary school Guidance \& Counseling , 29, 102-109. 
Stoel , L., 7 Lee, K.H. (2003). Modeling the effect of experience on student acceptance of web-based courseware. Internet research , 13, 364-375.

Sun,Y.(2010). Extensive writing in foreign -language classrooms : A blogging approach . Innovations in Education \& Teaching Internationally, 47(3), 327-339.

Viegas, F. B. (2006). Bloggers' expectations of privacy and accountability: An initial survey.Journal of Computer-Mediated Communication, 10(3) Published Online: 23 Jun 2006.Retrieved from http://jcmc.indiana.edu/vol10/issue3/viegas.html on January 30،2010.

Weller, M. (2004); E-portfolios: An assessment tool for online courses. British Journal of Educational Technology, 35(6)717-727.

Wood, P.K., 7 Lynch, C.L., (1998). Campus strategies: Using guided essays to assess and encourage reflective thinking. Assessment update , 10(2), 1416.

Xie, Y., Ke, F., \& Sharma, P. (2008). The effect of peer feedback for blogging on college students' reflective learning processes. Internet and Higher Education, 11, 18-25. 